\title{
EMPLOYMENT EXPERIENCES OF 127 DISCHARGED SCHIZOPHRENIC MEN IN LONDON
}

BY

\author{
ELIZABETH M. MONCK
}

Medical Research Council Social Psychiatry Research Unit, Institute of Psychiatry, Maudsley Hospital, London

The information on the work histories of discharged schizophrenic patients presented in this paper was collected as part of a wider study of the effects of family relationships on the course of the illness in patients with schizophrenia (Brown, Monck, Carstairs, and Wing, 1962). An important detail of the design enabled a common defect of follow-up studies to be partly overcome; the clinical condition of each patient was assessed at the time of discharge and could therefore be taken into account in the analysis of events in the follow-up period.

This paper has two purposes: to describe the employment history of these patients in the year after discharge, and to discuss the relationship of their work performance to clinical condition at discharge, to aspects of the past course of the illness, and to re-admission and deterioration in clinical condition during the follow-up period.

\section{Population}

Eight London mental hospitals were asked to notify us of the impending discharge of schizophrenic men between the ages of 20 and 49, who had been in hospital at least one month, and who were going to homes or lodgings in the London area. Those going to hostels, those not speaking English, and non-Europeans were excluded. From a total of 132 suitable patients seen at discharge, 128 patients were finally followed up for one year (97 per cent.), but the information on the work of one patient was so poor that he was excluded from the following results which therefore relate to 127 patients (96 per cent.).

These 132 patients are not necessarily representative of the population selected for study as we were not informed of the discharge of all suitable patients. However, they were comparable as a group, in number of previous admissions, age, and marital state, to the cohort of 178 male schizophrenic patients under 50 years of age covered in the study of admissions to three London hospitals in 1956 (Brown, Parkes, and Wing, 1961). 46 per cent. of the latter cohort were re-admitted during the first year after discharge, in comparison with 42 per cent. of the 127 patients in the present study.

\section{THE INTERVIEWS}

The following interviews were held with patients and relatives; the first three at the beginning of the year and the fourth at the end of the year. When a patient was re-admitted, an extra interview was held as soon after the event as possible. Interview procedures have been described in more detail in the earlier paper (Brown and others, 1962).

(1) All patients were seen a day or two before discharge by one of the two Unit psychiatrists, who checked the diagnosis and rated the patient on the presence of five "mental" symptoms shown in the interview. These were: flatness of affect, delusions, hallucinations, speech disorder, and other affects such as depression, anxiety, etc. Information given by a nurse who had been in charge of the patient during the previous week was used to rate five symptoms of ward behaviour: social withdrawal, motor activity, personal habits, bizarre behaviour, and anti-social behaviour.

(2) If the patient was returning to relatives, a visit was made by one of the two sociologists before the patient arrived home. The information taken from the hospital notes was checked and the relatives were asked for their opinion of the patient's discharge and their expectations of his chances of obtaining work in the coming year.

(3) The aim of the third interview, which took place about 2 weeks after discharge, was to assess the quality and amount of 'emotional involvement' 
between the patient and his "key" relative. Families were divided into those showing "high" or "low" emotional involvement with the patient. The techniques used to make this division are the subject of the earlier paper and are therefore not discussed here.

(4) An interview was completed for all patients at the end of the year, whether the patient had been re-admitted or not. In the case of patients living with relatives, the interview was made by the same sociologist who had visited the family at the start of the study.

(5) After re-admission, families and patients were interviewed as soon as possible.

\section{Measurement of Data}

Some of the methods used for measurement and classification of the data are described below:

(1) Overall Rating of Deterioration during the Follow-up Period*

A comparison of clinical condition at discharge with that at the end of the year (or on re-admission) was made on the evidence of hospital notes, comments of relatives, and, whenever possible, an interview with the patient. Systematic assessment of the ten items of clinical condition which were covered by the psychiatrist at discharge was made by the sociologist, who rated the patient on the following scale:

(i) Definitely much worse;

(ii) Definitely worse;

(iii) Possibly worse;

(iv) Same;

(v) Same or better, but worse at some time during the year;

(vi) Possibly better;

(vii) Definitely better.

\section{(2) Length of Time at Work}

It was possible to express the total length of time a patient was at work during the follow-up period in two ways; either as the number of months employed, or as a proportion of the number of months spent out of hospital.

Both methods have disadvantages. Comparison of the number of months patients have worked disguises the difference between unemployment when

* N.B. The term "follow-up period" is used throughout to describe the time up to the first re-admission for any patient who returned to hospital, but the whole year for those who were not re-admitted. living in the community, and unemployment during a stay in hospital. This distinction is made by a measure of the proportion of time out of hospital that a patient spends working, but such a measure disguises the actual amount of time at work and would equate a man who worked 3 months from discharge to the day before his re-admission with a man who worked for the whole year.

Despite this, the first measure has been used to present the main results, although the second measure has been used when it illuminated a particular point.

\section{(3) Expectations of Relatives Concerning Patients'} Prospects of Employment

In the interview before the patient returned home, the key person was asked three questions, and the answers were subsequently classified as follows:

(a) "What sort of job do you think your (relative) will do now?"

(i) A job at the highest occupational level ever achieved;

(ii) A job at a level lower than his peak;

(iii) Not sure what sort of job;

(iv) None.

(b) "How do you feel about his doing this work (or being unemployed)?"

(i) Satisfied;

(ii) Dissatisfied.

(c) "What would you think if he remained unemployed?"

(i) Satisfied (accepting);

(ii) Dissatisfied (concerned);

(iii) Rejecting (won't tolerate it).

\section{RESULtS}

\section{Description of Work Experiences}

Clinical Condition at Follow-up.-69 patients (54 per cent.) had deteriorated in clinical condition since discharge, either by the time they were readmitted (53 patients), or by the end of the year if they were not re-admitted (16 patients). 53 patients (42 per cent.) were re-admitted at least once, 29 were discharged, and eighteen remained out of hospital for the rest of the year.

Number of Months at Work.-Table I (opposite) shows the number of months the patients spent at work in the year as a whole, and in the period up to 
any first re-admission. This distinction takes account of the fact that seventeen of the 29 patients who were re-admitted and then discharged again within the year worked in their second discharge period.

TABLE I

NUMBER OF MONTHS WORKED IN THE WHOLE YEAR AND IN THE FIRST DISCHARGE PERIOD ONLY

\begin{tabular}{|c|c|c|c|c|}
\hline \multirow{2}{*}{$\begin{array}{l}\text { Number of } \\
\text { Months } \\
\text { at Work }\end{array}$} & \multicolumn{2}{|c|}{$\begin{array}{l}\text { During the } \\
\text { Whole Year }\end{array}$} & \multicolumn{2}{|c|}{$\begin{array}{l}\text { In the Period up to } \\
\text { First Re-admission }\end{array}$} \\
\hline & No. & Per cent. & No. & Per cent. \\
\hline $\begin{array}{c}12 \\
8 \text { to } 11 \\
4 \text { to } 7 \\
\text { Less than } 4 \\
\text { Unemployed }\end{array}$ & $\begin{array}{l}29 \\
32 \\
18 \\
27 \\
21\end{array}$ & $\begin{array}{l}23 \\
25 \\
14 \\
21 \\
17\end{array}$ & $\begin{array}{l}29 \\
28 \\
13 \\
31 \\
26\end{array}$ & $\begin{array}{l}23 \\
22 \\
10 \\
24 \\
20\end{array}$ \\
\hline Total & 127 & 100 & 127 & 99 \\
\hline
\end{tabular}

In the year as a whole 23 per cent. of the 127 patients worked for 12 months, and 17 per cent. did no work at all; 25 per cent. worked for 8 to 11 months, 14 per cent. for 4 to 7 months, and 21 per cent. less than 4 months. This measure was highly related to the proportion of time spent at work while out of hospital. Only sixteen patients (13 per cent.) fell into different categories in the two classifications.

Number of Patients employed in Each Month after Discharge.-The number of patients employed in each month after discharge was calculated-patients were counted as "working" if they held a job for more than 14 days in the month. All patients were included who were out of hospital for more than 14 days in the month, including those who had been discharged again after a re-admission to hospital. The number of patients employed remained more or less constant throughout the 12 months after discharge-an average of 55 per cent. of the 127 patients were employed in any month after discharge (range 49 to 60 per cent.). During the first 6 months after discharge an average of only one-quarter of the unemployed patients was in hospital, but over the last 6 months an average of nearly one-half the unemployed patients was in hospital.

Occupational Level.-Patients' occupations in the follow-up period (i.e. to to any first re-admission) were classified on the Hall-Jones scale of occupational status (Hall and Jones, 1950). Of the 101 patients who were employed, seventeen worked in clerical jobs, sixteen in skilled manual work, 27 in semi-skilled manual work, and 39 in unskilled manual work. (Two patients could not be classified). Only one patient changed his status during the follow-up period, when he was made a foreman.
Way of Finding Work.-Information on how men found their work was obtained only for the period up to any first re-admission. A third of the men (41) had a job prepared at the time of discharge: 35 returned to former employers, and the other six were given help by hospital social workers in arranging a new job before discharge.

Among those with no job prepared, 25 men found work on their own initiative, either by answering advertisements or by applying personally to firms in the hope of finding a vacancy. A large number of men visited the Employment Exchanges to collect benefit, but only 28 men were directly supervised by the Exchanges in obtaining a job. These 28 have been grouped with five men who found work with the help of their families or their Unions, in a single category referred to as the Employment Exchange group. (It was not known how two found their work.) The remaining 26 men did no work during the follow-up period.

The method of finding work was related to the length of initial unemployment before finding the first job. The 41 men with a job prepared started after an average of one week's initial unemployment, the 25 men who found work on their own initiative were unemployed for an average of $6 \frac{1}{2}$ weeks, and the 33 men who relied on the Employment Exchanges, for an average of $10 \frac{1}{2}$ weeks before starting their first job.

The Employment Exchange group also had a poorer performance in terms of total number of months in work during the follow-up period. Table II shows that this is not due solely to the longer time spent unemployed before finding the first job. The amount of unemployment after finding a job was calculated as a proportion of the time between starting the first job and the end of the follow-up period. Of 41 men with jobs prepared, four (10 per cent.) spent more than a quarter of the time after starting a job unemployed, compared with five ( 20 per cent.)

\section{TABLE II}

WAY OF FINDING FIRST JOB AND PROPORTION OF TIME SPENT UNEMPLOYED AFTER STARTING WORK

\begin{tabular}{|c|c|c|c|c|c|c|c|}
\hline \multirow{3}{*}{$\begin{array}{c}\text { Percentage } \\
\text { of Time } \\
\text { Unemployed } \\
\text { after } \\
\text { starting } \\
\text { First Job }\end{array}$} & \multicolumn{7}{|c|}{ Way of Finding First Job } \\
\hline & \multicolumn{2}{|c|}{$\begin{array}{c}\text { Job } \\
\text { Prepared } \\
\text { at } \\
\text { Discharge }\end{array}$} & \multicolumn{2}{|c|}{$\underset{\text { Initiative }}{\text { Own }}$} & \multicolumn{2}{|c|}{$\begin{array}{l}\text { Employment } \\
\text { Exchanges, } \\
\text { Unions, } \\
\text { etc. }\end{array}$} & \multirow[t]{2}{*}{$\begin{array}{c}\text { Not } \\
\text { Known }\end{array}$} \\
\hline & No. & $\begin{array}{l}\text { Per } \\
\text { cent. }\end{array}$ & No. & $\begin{array}{c}\text { Per } \\
\text { cent. }\end{array}$ & No. & $\begin{array}{c}\text { Per } \\
\text { cent. }\end{array}$ & \\
\hline $\begin{array}{l}<25 \\
>25\end{array}$ & $\begin{array}{r}37 \\
4\end{array}$ & $\begin{array}{l}90 \\
10\end{array}$ & $\begin{array}{r}20 \\
5\end{array}$ & $\begin{array}{l}80 \\
20\end{array}$ & $\begin{array}{l}17 \\
16\end{array}$ & $\begin{array}{l}52 \\
48\end{array}$ & $\overline{2}$ \\
\hline Total & 41 & 100 & 25 & 100 & 33 & 100 & 2 \\
\hline
\end{tabular}


of the 25 men finding jobs on their own initiative, and sixteen ( 48 per cent.) out of 33 men relying on the Employment Exchanges.

This relationship between the way of obtaining the first job and the length of subsequent employment remained when the level of occupation was taken into account. Table III shows that among clerical and skilled manual workers seventeen had a job prepared at discharge, eleven found jobs through their own initiative, and five had jobs found for them by the Employment Exchanges; the proportions unemployed more than a quarter of the time after starting their first job were 6,9 and 40 per cent. respectively in the three groups. Among semi-skilled and unskilled manual workers, 23 had a job prepared, fourteen found work on their own initiative, and 28 had work found for them by Employment Exchanges; the proportions unemployed more than a quarter of the time after starting work were respectively 13,29 , and 50 per cent.

An association between the level of occupation and the number of months at work in the follow-up period disappeared when the way in which the job was found was held constant.

Relatives' Expectations of Employment.-Answers to the three questions on the patient's chances of employment were combined to form an overall rating of high, medium, or low expectations. There were no significant differences in the proportions of wives and parents who had high, medium, or low expectations on the combined ratings.

Specific expectations of the level of work the patient would attain were related to whether he had already declined in occupational status before the key admission. Of the patients with no history of decline in occupation, 53 per cent. were expected to retain their highest occupational level, compared with only 30 per cent. of those who had declined one or two points (on the eight points of the revised Hall-Jones scale of occupations), and 21 per cent. of those who had declined three or more points.

Neither overall ratings of expectations nor individual questions were related to the length of time the patients worked during the follow-up period.

Overall Assessment of Work through the Year.-It was found valuable to divide the patients into six groups on the basis of three considerations: the amount of time spent working while out of hospital, the number of job changes, and whether by the second half of the year the patient showed evidence of stability at work. This showed that half the patients had made a fair or good work adjustment during their time out of hospital.

Group 1.-Thirty patients had one job only which they held for more than 10 months in the year; all were working throughout the second half of the year and at the time of follow-up. None of these patients was re-admitted, but five had deteriorated in behaviour, in their homes at least, by the end of the year.

Example: Mr. D. returned to his former employer. His colleagues knew of his illness and "remembered how I was then". He was sensitive to this and thought that some held it against him, particularly when the question of promotion came up towards the end of the year. The fact that he was promoted suggests that he had achieved at least a satisfactory level in his work.

Group 2.-Twenty patients were characterized by multiple job changes, at least half the jobs being lost

TABLE III

WAY OF FINDING FIRST JOB, AMOUNT OF UNEMPLOYMENT AFTER STARTING FIRST JOB, AND OCCUPATIONAL LEVEL

\begin{tabular}{|c|c|c|c|c|c|c|c|c|c|c|c|c|}
\hline \multirow{4}{*}{$\begin{array}{l}\text { Percentage of Time } \\
\text { Unemployed after } \\
\text { starting First Job }\end{array}$} & \multicolumn{12}{|c|}{ Occupational Level of First Job } \\
\hline & \multicolumn{6}{|c|}{ Clerical and Skilled Manual } & \multicolumn{6}{|c|}{ Semi-skilled and Unskilled Manual } \\
\hline & \multicolumn{2}{|c|}{$\begin{array}{c}\text { Job Prepared } \\
\text { at } \\
\text { Discharge }\end{array}$} & \multicolumn{2}{|c|}{$\begin{array}{c}\text { Job Found } \\
\text { by Own } \\
\text { Initiative }\end{array}$} & \multicolumn{2}{|c|}{$\begin{array}{l}\text { Job Found by } \\
\text { Employment } \\
\text { Exchange, } \\
\text { etc. }\end{array}$} & \multicolumn{2}{|c|}{$\begin{array}{c}\text { Job Prepared } \\
\text { at } \\
\text { Discharge }\end{array}$} & \multicolumn{2}{|c|}{$\begin{array}{c}\text { Job Found } \\
\text { by Own } \\
\text { Initiative }\end{array}$} & \multicolumn{2}{|c|}{$\begin{array}{c}\text { Job Found by } \\
\text { Employment } \\
\text { Exchange, } \\
\text { etc. }\end{array}$} \\
\hline & No. & $\begin{array}{c}\text { Per } \\
\text { cent. }\end{array}$ & No. & $\begin{array}{c}\text { Per } \\
\text { cent. }\end{array}$ & No. & $\begin{array}{c}\text { Per } \\
\text { cent. }\end{array}$ & No. & $\begin{array}{c}\text { Per } \\
\text { cent. }\end{array}$ & No. & $\begin{array}{c}\text { Per } \\
\text { cent. }\end{array}$ & No. & $\begin{array}{c}\text { Per } \\
\text { cent. }\end{array}$ \\
\hline $\begin{array}{l}<25 \\
>25\end{array}$ & $\begin{array}{r}16 \\
1\end{array}$ & $\begin{array}{r}94 \\
6\end{array}$ & $\begin{array}{r}10 \\
1\end{array}$ & $\begin{array}{r}91 \\
9\end{array}$ & $\begin{array}{l}3 \\
2\end{array}$ & $\begin{array}{l}60 \\
40\end{array}$ & $\begin{array}{r}20 \\
3\end{array}$ & $\begin{array}{l}87 \\
13\end{array}$ & $\begin{array}{r}10 \\
4\end{array}$ & $\begin{array}{l}71 \\
29\end{array}$ & $\begin{array}{l}14 \\
14\end{array}$ & $\begin{array}{l}50 \\
50\end{array}$ \\
\hline Totals & 17 & 100 & 11 & 100 & 5 & 100 & 23 & 100 & 14 & 100 & 28 & 100 \\
\hline
\end{tabular}


or left for reasons connected with the illness. However, all the patients worked for more than 9 months in the year and only two had deteriorated in clinical condition at the end of the year. These patients had made a fair adjustment to the demands of work but apparently at the expense of stability.

Example: Mr. L., who had four clerical jobs in the year, the longest of which he held for 8 months. He left this because he "knew" the girls in the same room used to laugh and talk about him. It is possible that he talked to himself at work, as it was observed he did so in the follow-up interview.

Group 3.-Twelve patients did not start well but had settled down to work by the last quarter of the year; seven were unemployed for the first 6 months but remained out of hospital, and five were readmitted before settling down in one job. These patients are characterized by having some difficulty finding their jobs but eventually settling down to work well.

Example: Mr. N. spent $6 \frac{1}{2}$ months looking for work in a laboratory because of his interest in "science", but after pressure from the psychiatrist at his Out-Patient Clinic and Employment Exchange officials he took a job washing cars "temporarily". He continued to spend time looking for laboratory work but appeared to be working efficiently meanwhile.

Group 4.-Twenty patients worked more than half their time out of hospital and at least 2 months in the year. Patients in this group characteristically held only one job and, having lost this for reasons clearly associated with their illness, failed to get another. Sixteen were re-admitted to hospital within 4 weeks of losing their jobs and the four who were not readmitted were all unemployed at follow-up.

Example: Mr. E. returned to his former employer and worked for 6 months, showing increasing "signs of strain" at home (his father's description). However, at work he was thought to be performing well, and they were very surprised to learn that he had been re-admitted to hospital shortly after returning home one evening. $\mathrm{He}$ was not discharged until after the end of the follow-up period, but his firm said they were prepared to accept him back as "a good, steady worker".

Group 5.-Twelve of this group of 23 spent less than 6 weeks in one job, and the other eleven were characterized by frequent jobs changes over a period of less than 6 months. With the exception of one man who left jobs because they did not suit his tuberculous condition, all these patients lost or left jobs for reasons connected with their clinical condition.

GROUP 6.-21 patients were completely unemployed throughout the year. Eight of them tried to find work. One patient in the group was waiting to attend an Industrial Rehabilitation Unit.

\section{RELATION OF WORK TO OUTCOME}

Clinical Condition at Discharge and Work.-The ratings of mental symptoms at discharge showed only small relationships with the number of months at work in the follow-up period and the proportion of time spent at work while out of hospital. 45 per cent. of the patients who worked 12 months were rated as showing at least one moderate or severe mental symptom at discharge, compared with 60 per cent. of those who worked 10 to 11 months, 59 per cent. of those who worked 2 to 9 months, and 68 per cent. of those who worked less than 2 months or not at all. Ratings of ward behaviour symptoms, however, were more highly related to the two measures of work (in each case at a significance level of $<\cdot 01$ ); for example, 35 per cent. of the patients who worked 12 months, 50 per cent. of those who worked 10 to 11 months, 71 per cent. of those who worked 2 to 9 months, and 73 per cent. of those who worked less than 2 months or not at all, showed at least one ward behaviour symptom to a moderate or severe degree at discharge.

Among 101 patients who worked during the follow-up period, the length of initial unemployment before finding the first job was not related to ratings of mental symptoms or ward behaviour made at the time of discharge.

This lack of a strong association between the five mental symptoms and subsequent work history may be further illustrated. Fifteen patients who worked for more than 75 per cent. of the time they were out of hospital were rated moderate or severe on at least one mental symptom at discharge and continued to show these symptoms in the home, while at the same time going out to work. Thirteen of these fifteen men showed severe delusions about which they talked freely in their homes; the delusions were accompanied by pressure of talk (2), considerable hostility or suspiciousness (9), and talking to themselves (3). Two of the fifteen men showed severely flat and incongruous affect and some suspiciousness.

Characteristics of the Patient at Discharge.Thirteen items describing characteristics of the patient at the time of discharge were recorded. The 
following eight items showed little or no relation to length of time at work in the follow-up period; number of previous admissions; age at discharge; educational level of patient; years since first admission; father's usual occupational level; patient's highest occupational level; marital status at the key admission; disturbed behaviour at the key admission. This last item recorded the presence of delusions centering on the family, attempted suicide, violence, destructive behaviour, or sexual misconduct.

Table IV lists the five attributes which showed the largest relationship with length of time at work: age under 20 at first admission; decline in occupational level in the 2 years before admission; length of key stay over 6 months; more than 12 months' unemployment in the 2 years before discharge (including any time in hospital); evidence of a complete lack of interest in women throughout the patient's past history. Table IV shows that these items were related to whether patients worked more than 6 months in the year. (These items were also related to whether patients worked more than 10 months in the year.)

TABLE IV

CHARACTERISTICS OF THE PATIENTS AT TIME OF DISCHARGE AND NUMBER OF MONTHS AT WORK IN FOLLOW-UP PERIOD

\begin{tabular}{|c|c|c|c|c|}
\hline \multirow{2}{*}{\multicolumn{2}{|c|}{ Predictive Items in Patient's History }} & \multirow{3}{*}{$\begin{array}{c}\begin{array}{c}\text { Total } \\
\text { Patients }\end{array} \\
13 \\
114\end{array}$} & \multicolumn{2}{|c|}{$\begin{array}{l}\text { Employed } \\
\text { less than } \\
6 \text { Months }\end{array}$} \\
\hline & & & \multirow{2}{*}{$\begin{array}{r}\text { No. } \\
9 \\
53\end{array}$} & \multirow{2}{*}{$\begin{array}{r}\text { Per } \\
\text { cent } \\
69 \\
47\end{array}$} \\
\hline $\begin{array}{c}\text { (i) Age at First Admission } \\
\text { (yrs) } \ldots\end{array}$ & 20 & & & \\
\hline $\begin{array}{l}\text { (ii) Occupational Level in } \\
2 \text { yrs before Admis- } \\
\text { sion . }\end{array}$ & $\begin{array}{c}\text { Decline } \\
\text { No Decline }\end{array}$ & $\begin{array}{l}49 \\
78\end{array}$ & $\begin{array}{l}30 \\
32\end{array}$ & $\begin{array}{l}61 \\
41\end{array}$ \\
\hline (iii) $\underset{\text { (mths) }}{\text { Length of Key Stay* }}$ & $\begin{array}{r}3 \\
3-5 \\
6-4\end{array}$ & $\begin{array}{l}60 \\
35 \\
32\end{array}$ & $\begin{array}{l}20 \\
17 \\
25\end{array}$ & $\begin{array}{l}33 \\
49 \\
78\end{array}$ \\
\hline $\begin{array}{l}\text { (iv) Peak Level of Adjust- } \\
\text { ment with Women* }\end{array}$ & $\begin{array}{l}\text { Ever Married } \\
\text { Steady } \\
\text { Casual } \\
\text { No Interest }\end{array}$ & $\begin{array}{l}34 \\
16 \\
35 \\
42\end{array}$ & $\begin{array}{r}14 \\
7 \\
13 \\
28\end{array}$ & $\begin{array}{l}41 \\
44 \\
37 \\
67\end{array}$ \\
\hline $\begin{array}{l}\text { (v) Months of Unemploy- } \\
\text { ment in } 2 \text { yrs before } \\
\text { Discharge, including } \\
\text { Time in Hospital*.. }\end{array}$ & $\overleftarrow{12+}$ & $\begin{array}{l}64 \\
63\end{array}$ & $\begin{array}{l}15 \\
47\end{array}$ & $\begin{array}{l}24 \\
75\end{array}$ \\
\hline Total & $\ldots$ & 127 & 62 & 49 \\
\hline
\end{tabular}

* Significant at $<\cdot 01$ level.

When the amount of unemployment in the 2 years before discharge was allowed for, the relationship of length of time at work and previous decline in occupational level disappeared. Similarly, the nine patients aged less than 20 years at first admission who worked less than 6 months in the follow-up period had all been unemployed more than 12 months in the 2 years before discharge. Only three of the items therefore (length of key stay, level of interest in women, and unemployment in the 2 years before discharge) showed, independently of each other, a significant relationship with length of time in work in the follow-up period.

Table $\mathrm{V}$ shows that combinations of these items distinguish three groups of patients on the basis of the length of time at work. 75 per cent. of the 63 patients who were unemployed for more than 12 months in the 2 years before discharge worked less than 6 months in the follow-up period; 41 per cent. of the seventeen patients who scored positively on either or both of the two remaining items, but not on unemployment before discharge, worked less than 6 months; and 17 per cent. of the 47 patients with none of these characteristics worked less than 6 months. The relationship of each group with the number of months at work remained when readmission to hospital was allowed for; the three factors predicted the work performance as well for patients who were re-admitted during the year as for those remaining out of hospital. The addition, first, of the rating of mental and ward behaviour symptoms at discharge and, second, of the rating of the relationship of the patient with his relative at discharge did not increase the efficiency of these predictions.

\section{TABLE V}

PREDICTION OF NUMBER OF MONTHS IN WORK DURING THE FOLLOW-UP PERIOD

\begin{tabular}{|c|c|c|c|c|c|c|}
\hline \multirow{3}{*}{$\begin{array}{l}\text { Predictive Items in } \\
\text { Patient's history }\end{array}$} & \multicolumn{6}{|c|}{ Number of Months at Work } \\
\hline & \multicolumn{2}{|c|}{$6+$} & \multicolumn{2}{|c|}{6} & \multicolumn{2}{|c|}{ Total } \\
\hline & No. & $\begin{array}{c}\text { Per } \\
\text { cent. }\end{array}$ & No. & $\begin{array}{c}\text { Per } \\
\text { cent. }\end{array}$ & No. & $\begin{array}{l}\text { Per } \\
\text { cent. }\end{array}$ \\
\hline 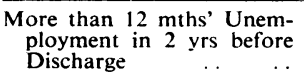 & 16 & 25 & 47 & 75 & 63 & 100 \\
\hline $\begin{array}{l}\text { Poor Adjustment with } \\
\text { Women and/or Key Stay } \\
\text { Longer than } 6 \text { mths }\end{array}$ & 10 & 59 & 7 & 41 & 17 & 100 \\
\hline None & 39 & 83 & 8 & 17 & 47 & 100 \\
\hline Total & 65 & 51 & 62 & 49 & 127 & $\overline{100}$ \\
\hline
\end{tabular}

However, having a job prepared at discharge affected the prediction significantly. Table VI (opposite) shows that the proportion of patients working less than 6 months in the follow-up period is much greater in each of the three predictive categories when a job is not prepared at discharge. 
TABLE VI

PREDICTION OF NUMBER OF MONTHS AT WORK DURING THE FOLLOW-UP PERIOD RELATED TO WHETHER JOB WAS PREPARED AT DISCHARGE

\begin{tabular}{|c|c|c|c|c|c|c|c|}
\hline \multirow{3}{*}{$\begin{array}{l}\text { Predictive Items in } \\
\text { Patient's History }\end{array}$} & \multirow{3}{*}{$\begin{array}{c}\text { Job } \\
\text { Prepared } \\
\text { at } \\
\text { Discharge }\end{array}$} & \multicolumn{6}{|c|}{ Number of Months at Work } \\
\hline & & \multicolumn{2}{|c|}{$6+$} & \multicolumn{2}{|c|}{$<6$} & \multicolumn{2}{|c|}{ Total } \\
\hline & & No. & $\begin{array}{c}\text { Per } \\
\text { cent. }\end{array}$ & No. & $\begin{array}{c}\text { Per } \\
\text { cent. }\end{array}$ & No. & $\begin{array}{l}\text { Per } \\
\text { cent. }\end{array}$ \\
\hline \multirow{2}{*}{$\begin{array}{l}\text { More than } 12 \text { mths' } \\
\text { Unemployment in } \\
2 \text { yrs before Dis- } \\
\text { charge } \quad . . \quad 1 .\end{array}$} & No & 10 & 19 & 42 & 81 & 52 & 100 \\
\hline & Yes & 6 & 55 & 5 & 45 & 11 & 100 \\
\hline \multirow{2}{*}{$\begin{array}{l}\text { Poor Adjustment } \\
\text { with wo men } \\
\text { and/or Key Stay } \\
\text { more than } 6 \text { mths }\end{array}$} & No & 5 & 45 & 6 & 55 & 11 & 100 \\
\hline & Yes & 5 & 83 & 1 & 17 & 6 & 100 \\
\hline \multirow{2}{*}{ None } & No & 17 & 74 & 6 & 26 & 23 & 100 \\
\hline & Yes & 22 & 92 & 2 & 8 & 24 & 100 \\
\hline
\end{tabular}

Deterioration and Re-admission in Relation to Work.-The design of this study did not allow a rigorous analysis to be made of whether work was associated with lower deterioration or re-admission rates than unemployment. But despite the problems connected with looking for an answer in these data, a preliminary analysis was made.

There was an association between re-admission and the number of months at work in the follow-up period: the proportions re-admitted among 29 men who worked 12 months, 36 men who worked 6 to 11 months, and 62 men who worked less than 6 months, were 0,31 , and 68 per cent. respectively. This association must be at least partly tautological, as a patient clearly could not work longer than the time he was out of hospital. However, there was also a statistically significant association between the proportion of time spent working while out of hospital (before the first re-admission) and readmission. The proportions re-admitted among 37 men who worked all their time out of hospital, among forty who worked more than half the time, and among fifty who worked less than half the time were 22,38 , and 60 per cent. respectively.

Clinical deterioration, like re-admission to hospital, is related both to the number of months at work in the follow-up period and to the proportion of time at work while out of hospital. In neither instance, of course, can the relationship be used to show that the re-admission or the deterioration is the result of unemployment or vice-versa.

The Living Group and Work.-It has already been noted that wives and parents did not differ in their overall expectations of the patient's chances of work (seven "other relatives" formed a group too small for comparison). There were certain differences in subsequent performance: 75 per cent. of the 24 men living with their wives worked more than half the follow-up period compared with 49 per cent. of the 65 unmarried men living with parents. 28 unmarried men living with siblings or in lodgings showed a record very similar to the husbands, 73 per cent. working more than half the follow-up period. Of ten men who had been married and now lived with parents (5), in lodgings (4), or with siblings (1), 70 per cent. had worked more than half the follow-up period. However, Table VII shows that these differences largely disappear when the amount of unemployment before discharge is taken into account.

TABLE VII

PERCENTAGE OF TIME SPENT AT WORK BY MEN LIVING WITH WIVES AND UNMARRIED MEN LIVING WITH PARENTS, BY UNEMPLOYMENT IN THE 2 YEARS BEFORE DISCHARGE

\begin{tabular}{|c|c|c|c|c|c|c|c|c|}
\hline \multirow{3}{*}{\multicolumn{2}{|c|}{ Living Group }} & \multirow{3}{*}{$\begin{array}{c}\text { Percentage } \\
\text { of Time } \\
\text { Spent at } \\
\text { Work } \\
\text { while } \\
\text { out of } \\
\text { Hospital }\end{array}$} & \multicolumn{6}{|c|}{$\begin{array}{l}\text { Months of Unemployment in } \\
2 \text { yrs before Discharge }\end{array}$} \\
\hline & & & \multicolumn{2}{|c|}{$<12$} & \multicolumn{2}{|c|}{$12+$} & \multicolumn{2}{|c|}{ Total } \\
\hline & & & No. & $\begin{array}{l}\text { Per } \\
\text { cent. }\end{array}$ & No. & $\begin{array}{l}\text { Per } \\
\text { cent. }\end{array}$ & No. & $\begin{array}{c}\text { Per } \\
\text { cent. }\end{array}$ \\
\hline $\begin{array}{c}\text { Married } \\
\text { Wives }\end{array}$ & $\begin{array}{cr}\text { Men } & \text { with } \\
\ldots & \ldots\end{array}$ & $\begin{array}{l}50+ \\
<50\end{array}$ & $\begin{array}{r}14 \\
2\end{array}$ & $\begin{array}{l}88 \\
12\end{array}$ & $\begin{array}{l}4 \\
4 \\
\end{array}$ & $\begin{array}{l}50 \\
50\end{array}$ & $\begin{array}{r}18 \\
6\end{array}$ & $\begin{array}{l}75 \\
25\end{array}$ \\
\hline \multicolumn{2}{|c|}{$\begin{array}{c}\text { Unmarried Men } \\
\text { with Parents }\end{array}$} & $\begin{array}{l}50+ \\
<50\end{array}$ & $\begin{array}{r}20 \\
3\end{array}$ & $\begin{array}{l}87 \\
13\end{array}$ & $\begin{array}{l}12 \\
30\end{array}$ & $\begin{array}{l}28 \\
72\end{array}$ & 32 & $\begin{array}{l}49 \\
51\end{array}$ \\
\hline
\end{tabular}

One man out of 26 in lodgings ( 4 per cent.), three out of 24 with wives (13 per cent.), and 21 out of seventy with parents ( 30 per cent.) did no work at all during the follow-up period. This difference remains clear when unemployment in the 2 years before discharge is controlled.

Patients living with relatives who worked full-time or part-time did not differ in the proportion of time at work during their time out of hospital from patients living in households where no other person was working.

\section{Discussion}

In any one month of the follow-up year, roughly one-half of this group of 127 schizophrenic men were in full-time employment. In the year as a whole, one-quarter of the patients were judged to have worked satisfactorily, holding one or two jobs but remaining at work for 12 months. A further quarter, all of whom were re-admitted during the year, were thought to have worked satisfactorily for most of their time out of hospital. One-third of the patients characteristically lost their jobs for reasons connected with their clinical condition, frequently experiencing difficulty in obtaining another job and 
periods of unemployment; many of these men were re-admitted. The remaining one-sixth did no work while they were out of hospital during the year.

The majority of the one-quarter with the most satisfactory work record went to jobs that had been prepared before discharge, and most commonly to their former employer. There were marked differences in the length of time at work during the follow-up period between those who had a job prepared at discharge and those who did not; the latter group worked, on average, for shorter absolute periods and for a smaller proportion of their time out of hospital. When the 41 patients with a job prepared at discharge were compared with the sixty patients who found work after discharge, statistically significant differences were found in the amount of unemployment experienced in the 2 years before discharge, and in the highest level of interest in and adjustment with women: measures which related, independently of each other, to length of work in the follow-up period.

Among patients who did not have a job prepared, those who found work on their own initiative worked for a greater number of months and a greater proportion of their time than those who found work with the help of agencies such as Unions, families, or Employment Exchanges. The difference between these two groups was shown both in the length of time taken to find the first job, and the proportion of time unemployed after the first job was begun.

Certain similarities between the results of this study and of some other follow-up studies are worth noting, although comparisons are complicated by the wide variation in the length of follow-up and the type of patients studied:

(1) The proportions of patients in the current study who did no work in the follow-up period, and the smaller group who did no work at all in the whole year, are very similar to the proportions found in four other studies in which work histories were obtained. In the present study 20 per cent. were unemployed throughout the follow-up period, and 17 per cent. throughout the whole year. Harris, Linker, Norris, and Shepherd (1956) reported that 18 per cent. of 126 schizophrenic patients were completely unemployed over a 5-year period; Adler (1955) found that 18 per cent. were completely unemployed among men of all diagnoses discharged from Arkansas State Hospital between 1 and 19 years before the follow-up: Freeman and Simmons (1962) recently found that 27 per cent. of men
(78 per cent. of whom were diagnosed as schizophrenic) were totally unemployed during the year after discharge.

(2) The proportion working regularly from discharge up to re-admission or to the follow-up interview is also very similar in the present study (29 per cent. working the whole time out of hospital), in Adler's study (34 per cent. among men), and in Freeman and Simmons's study (28 per cent. among men).

(3) The current study gives results which could be used to confirm Adler's observation that married men work "more regularly more frequently", and Freeman and Simmons's finding that men living with their wives were more likely to show a "high" occupational performance than men living with their parents. ("High" in this context referred to regularity and length of time in work.) Freeman and Simmons interpreted this as a result partly of the greater "rehabilitation potential" of the married men, due to the selective process of marriage, and reported that "married male patients are significantly more likely than single patients to perform occupationally at high levels before hospitalization as well as afterward". These authors do not, however, rule out entirely the effects of the different levels of tolerance of deviant behaviour in marital and parental homes. In the present study 75 per cent. of the men living with wives worked more than half their time out of hospital compared with 49 per cent. of the 65 unmarried men living with parents. This difference disappeared, however, when the amount of unemployment in the 2 years before discharge was taken into account, which suggests that the estimate of "rehabilitation potential" in the area of work could be based more usefully on previous work records than on the type of living group to which the patient returned.

This concept of "rehabilitation potential" introduces the question how far performance at work during the following year may be predicted. At the time of discharge three items referring to the patient's previous history could be used to predict the amount of work in the follow-up period: length of key stay in hospital, amount of unemployment in 2 years before discharge (including any time in hospital), and level of interest in or adjustment with women.

It is clear that these characteristics, though not strictly of a clinical nature, nevertheless reflect 
certain aspects of the severity and length of the illness and, at the least, indicate the extent to which the disease has affected past social achievement. It is therefore perhaps not surprising that these three items should predict one sphere of social achievement in the follow-up year-namely work-more effectively than the clinical measures made at discharge when the schizophrenic patient might be expected to be, clinically, at or near his best.

Of the two clinical ratings made at discharge, the ratings of mental symptoms were not related to length of time at work in the follow-up period, although they were related to re-admission during the year. Ratings of ward behaviour symptoms, on the other hand, showed a statistically significant relationship to work: 35 per cent. of those who worked 12 months, 50 per cent. who worked 10 to 11 months, 71 per cent. who worked 2 to 9 months, and 73 per cent. who worked less than 2 months or not at all during the follow-up period, showed at least one ward behaviour symptom to a moderate or severe degree at discharge.

It became clear, moreover, during the course of the study that it might be very misleading to treat a patient's clinical condition as a stable feature at any one time. For example, relatives sometimes reported that a patient who seemed very disturbed with family members could appear almost symptom-free, at least for a while, when in the presence of a stranger, and then relapse again when alone with the family. The design of the study demanded that the relatives with whom the patient lived should be used to supply the information about clinical condition at the end of the year or at re-admission. Some patients who were reported as very disturbed at home were known, from independent sources, to have appeared "quite normal" at work over the same period. It is almost certain that they would have been dismissed if they had behaved at work as they did at home. These observations emphasize the importance of describing the context of the clinical ratings and suggest a reason why the two clinical ratings made in hospital at the time of discharge do not predict the length of time at work while in the community with greater accuracy.

The results of this study cannot be used to show that the fact of being employed favourably affected the frequency or severity of symptoms shown by the patient in the home. Nevertheless, it was observed that for a small proportion of the patients employment was a necessary condition of staying out of hospital. When the patient continued to work though being or becoming very disturbed, the tolerance of his relatives was increased, as they explained, both by shortening the amount of time they had to spend with him, and by affirming that in one respect at least he was still socially competent. Evidence for the harmful influences of certain types of home relationships on the clinical condition of the patient has been discussed in a recent paper by Brown and others (1962). From the patient's point of view employment offered a means of escaping the influence of these relationships. These two considerations overlap the normal humanitarian and economic reasons for maintaining discharged mental patients, particularly men, in open or sheltered employment. In the course of the follow-up year only about one-third of these 127 men had any contact with the skilled services provided at the Employment Exchanges by the Disablement Resettlement Officers, and only one attended an Industrial Rehabilitation Unit (another man waited a whole year to attend). This study suggests that it is possible to distinguish at the time of discharge those patients on whom the fairly limited resources of the community services may most profitably be concentrated.

\section{SUMMARY}

This paper reports features of the employment histories of 127 schizophrenic men during the year after discharge from mental hospital.

(1) One-quarter of these patients were judged to have made a good work adjustment over the whole year; a further one-quarter made a good adjustment while out of hospital but were re-admitted during the year; one-third lost or left jobs for reasons connected with their psychiatric state and were often unemployed for long periods; one-sixth were never employed while out of hospital.

(2) Three aspects of the patient's previous history were related to the length of time at work during the follow-up period: length of key stay, level of adjustment with women, and amount of unemployment in the 2 years before discharge (including any time in hospital).

(3) Ratings of clinical condition made at discharge showed only a low degree of relationship to length of time at work. When the three items in (2) were taken into account, this relationship disappeared.

(4) One-third of the patients had a job prepared at discharge, the majority returning to former employers. This was associated with longer periods at 
work, and with working for a greater proportion of the time after the start of the patient's first job. This association remained when the three items in (2) were taken into account.

(5) It was concluded that the three items in (2) could be used to predict the length of time at work in the year after discharge. When information on whether a job was prepared at discharge was also taken into account, it was possible to distinguish patients whose work records were likely to be poor and on whom the limited resources of community support might be concentrated.

\section{REFERENCES}

Adler, L. M. (1955). "Patients of a State Mental Hospital: the Outcome of their Hospitalization", in "Mental Health and Mental Disorder", ed. A. M. Rose, pp. 501-523. Routledge and Kegan Paul, London.

Brown, G. W., Monck, E. M., Carstairs, G. M., and Wing, J. K. (1962). Brit. J. prev. soc. Med., 16, 55. Parkes, C. M., and Wing, J. K. (1961). J. ment. Sci., 107, 1070.

Freeman, H. E., and Simmons, O. A. (1962). "Posthospital Experience"'. Wiley, New York.

Hall, J., and Jones, D. Caradog (1950). Brit. J. Sociol., 1, 31.

Harris, A., Linker, I., Norris V., and Shepherd, M. (1956). Brit. J. prev. soc. Med., 10, 107.

\section{SOCIETY FOR SOCIAL MEDICINE}

In the account of the meeting held on September 27-29, 1962, which appeared in the last issue of this Journal (Brit. J. prev. soc. Med., 1963, 17, 45), the paper by Kessel and McCulloch should have been reported as follows:

Edinburgh's Attempted Suicides, by NeIL KESSEL and Wallace McCulloch (M.R.C. Unit for Research on the Epidemiology of Psychiatric Illness, Edinburgh): In one ward all cases of attempted suicide, defined as selfpoisoning or injury, are resuscitated and psychiatrically screened. More than one per thousand of the adult population are admitted annually.

The untreated consequences of the patient's action are categorized as: death (20 per cent.), death probable (12 per cent.), death unlikely (12 per cent.), and death impossible (56 per cent.), but severity of mental state does not run parallel.

90 per cent. use poisons, chiefly barbiturates.

Nine-tenths of the patients stay less than a week. 26 per cent. become psychiatric in-patients and 44 per cent. psychiatric out-patients; 30 per cent. need no further psychiatric supervision.

A similar rapid psychiatric screening service is advocated for every poison treatment centre. 